\title{
The role of agents in agricultural policies: intentions and reality
}

\section{Martine Dirven}

Agricultural Development

Unit, ECLAC.
Sectoral policies make explicit and implicit assumptions about the behaviour and capabilities of the agents (such as dynamic responses to market signals, demand-led assistance, collaborative efforts, participation in financing) which we consider to be rather unrealistic. Because of this lack of realism, policies that aim to be neutral often turn out to be highly exclusive. They fail to give sufficient importance to the special features of the sector -with its high climatic, biological and commercial risks and its slow adaptation- or to the fact that those who take decisions in agriculture are now mostly in an inferior position because of their incomes below the poverty line, their inadequate training, their traditions based on centuries of living in precarious conditions, and their geographical location in marginal areas, far from infrastructure and with only a minimum of services and sources of information. These people have only scanty and imperfect access to the markets which, according to the prevailing model, should govern decisions and the (re)distribution of the factors of production. In our opinion, this explains the patchy and lower-than-expected growth registered by the sector after the reforms to promote the liberalization of markets and external openness in the region. In view of the results of the application of the new model, it may be wondered whether Latin America can afford a form of development which excludes over half of its agricultural producers; what the alternatives are; and what costs and benefits each of them offers in terms of production and monetary, social, spatial and other aspects. The article outlines the changes in policies and their results at the aggregate level, summarizes the arguments usually put forward to explain agricultural performance in the region, and proposes a second set of explanations based on a description of the agents and the responses that may be expected from them, contrasting the latter with the supposedly neutral nature of the policies. 


\section{I}

\section{Introduction}

Various authors, such as Schejtman (1982), have highlighted the heterogeneity of agricultural producers and, hence, the need to formulate differential policies in order to obtain the desired results. This was done in the past, in the context of a paternalistic State, with policies that were often dictated from above and, of course, from the capital.

More recently, taking a similar but considerably more optimistic view, De Janvry and Sadoulet (1993) conclude that the present time should be particularly favourable for rural development, because there is now a better understanding of the dynamics of rural poverty, the logic behind agrarian institutions, and the political economy of the reforms.

In our opinion, however, the present situation points rather in the opposite direction: there is great emphasis on sectorally "neutral" macroeconomic policies, with considerable vagueness about the place of sectoral policies in the "model" and with only incipient emphasis on the definition of regional- and local-level promotional policies but much greater emphasis on demand-driven actions and services, so that it is the agents who take the initiative in such demand, which in many cases should be of a group nature.

Generally speaking, it was expected that the agricultural sector, which had been heavily burdened during the almost thirty years of import substitution policies, ${ }^{1}$ would now take advantage of the comparative advantages offered by the natural resources of the region and show all its potential for development and export growth. So far, however, its performance has been rather disappointing.

Microeconomic analyses are now beginning to be made $^{2}$ which conclude that while neutral policies have favoured exportable tradeable goods and -less predictably- some non-tradeables (ECLAC, 1997a), they have also favoured some groups more than others.

We feel that (supplementing a recent study on the influence of agents on policies (Binswanger and Deininger, 1997)) an analysis based on the real situation and capacity of the various agents to respond to different policies could help to explain why the sector as a whole has performed less well than was expected under the neoliberal model.

Consequently, after analysing the policy changes made and the indicators of the sector's performance, we wish to outline here some reflections which -based on the different socioeconomic characteristics of producers and the different degrees of use made of factors in the various agricultural and forestry products- try to indicate how they are affected by price signals, policies and instruments and how they are most likely to respond to them.

\section{II}

\section{Economic policies after 1980}

Since the mid-1980s, Latin America has experienced unprecedented changes, passing from a development strategy aimed at the domestic market, with strong public sector intervention, to an outward-looking strategy with deregulated markets, much fiscal control, and the private sector as the main agent of development. It was expected that this new approach

$\square$ The author wishes to thank Research Assistant Mónica Arellano for her valuable collaboration.

${ }^{1}$ See, for example, Krueger, Schiff and Valdés, 1990. would lead to rapid and more efficient growth, free from the distortions of the past.

We cannot really speak of the existence of a single new development model in the region. There is currently almost general agreement on the need to maintain the macroeconomic balances, to further trade and financial openness, to restrict activities by

\footnotetext{
${ }^{2}$ With regard to the industrial sector, see for example Peres
} (ed.), 1998. 
the State in the field of production, and to deregulate markets. There is less consensus, however, on the need to regulate and supervise the banking system; on the sequence in which reforms in the areas of trade, financial liberalization and exchange-rate policy should be carried out and on the prior need for a suitable institutional framework in the financial area; on the need for export promotion and sectoral and technological development policies; on privatization, and on the content and scope of labour reforms (ECLAC, 1995).

The reduction of inflation has undoubtedly been one of the main achievements. Other macroeconomic variables of key importance for the competitiveness of a tradeable sector such as agriculture have been tackled less effectively, how- ever: consequently, many of the national currencies of the region are overvalued, and interest rates are very high. Because of this situation and the fact that the reactions of the various agents were less vigorous than expected, even before the Asian crisis the 1990s was showing signs of ending with an average growth rate lower than that of the import substitution period and an income distribution pattern similar to or even more concentrated than that of the early $1980 \mathrm{~s}$.

Unfortunately, the division into two opposing camps of those in favour of the neoliberal model, on the one hand, and those who have serious misgivings about it, on the other, has not yet permitted a calm and dispassionate analysis and a constructive debate on this unexpectedly poor performance.

\section{III}

\section{Agricultural policies before and after 1980}

In general terms, it may be said that in the period from the 1950 s to the 1980 s there were sectoral policies in favour of agriculture, designed among other things to offset other policies with an industrial and urban slant. According to Krueger, Schiff and Valdés (1990), all in all the policies applied were not favourable to agriculture, since the macroeconomic policies applied had a serious negative impact which the sectoral policies in favour of agriculture did not manage to offset. ${ }^{3}$ Furthermore, the subsidies for inputs, water, credit and the prices of various services favoured those who used them most, that is to say, medium-sized and large commercial producers (Gómez Oliver, 1994).

Neoliberalism basically holds that (in conditions of perfect competition and information) it is the market that allocates resources best among various different uses and causes them to flow to the areas of activity which offer the greatest comparative advantages to the country and the economic agents.

\footnotetext{
${ }^{3}$ In this article, "agriculture" is used for the sake of simplicity, usually meaning the agricultural and livestock sector but also sometimes forestry and fisheries too.
}

The private sector thus becomes the main agent of change. ${ }^{4}$

Policies involving greater openness (lowering of tariffs and elimination of import and export hindrances, such as quotas and licences) are therefore a logical consequence of the neoliberal model, though the great importance attached to exports is not: it derives in fact from the need to achieve balanceof-payments equilibrium. Thus, although in industry it is essential (in medium-sized or small economies) to have an export-oriented strategy in order to take full advantage of the potential profits, this is not so in

\footnotetext{
${ }^{4}$ In its "Declaration of Santiago" the Ibero-American Agricultural Forum (Santiago, August 1996) asserted that private enterprise (whether in the shape of individually owned private concerns, cooperatives, companies, communities, or any other form) is the main agent of change and that the State must play a facilitating role aimed at strengthening a solid, broad and creative entrepreneurial base for the benefit of those who take the risk of embarking on business ventures and that of countries as a whole, though it tempered this assertion by also reaffirming the State's commitment to give support to agriculture, especially family peasant agriculture and cooperatives, as the most effective and realistic response for a broad segment of medium-sized and small agricultural producers for whom, for economic, social, environmental and cultural reasons, this option represents their possibility of development.
} 
TABLE 1

Latin America and the Caribbean: Main features

of changes in agricultural policies

\section{Policies in the 1950s to 1980 s}

Strong State centralism

State planning and financing of "public" goods and services

Concern for the food security of the country, with research therefore focussed on increasing production and yields of staple foods (rice, wheat, maize, potatoes, beans, lentils, etc.)

Free technical assistance, with programmes prepared by State bodies with little or no user participation

Subsidized credit through special lines of credit for the sector

Labour reforms leading to the monetization of the rural economy and the gradual disappearance of sharecropping-type systems, with their labour force being replaced by permanent or above all temporary wage labourers

Price controls for staple foodstuffs in order to check inflation and keep minimum wages low so as to encourage industrialization

Exchange rates favourable to imports

Tariff rates that were generally high but covered a wide range of rates

Taxes on agricultural exports

Agrarian reform programmes aimed at reducing the inefficiency of highly heterogeneous production systems (with abundant land and capital for a few agents and abundant labour in the case of the rest) and above all at reducing the possibility of social disorder in rural areas

\section{Present policies}

Political, institutional and financial decentralization aimed at serving local projects

Demand-oriented approach, with co-financing of investments in infrastructure and services

Demand-oriented approach, with co-financing of research both in public research institutes and in universities ${ }^{\text {a }}$

Paid private technical assistance in response to demand from producers, subject to presentation of a project for competition when subsidies are involved

Elimination of specific lines of credit for the agricultural sector, of development banks, and of the obligation of private banks to loan a certain proportion of their portfolio to the sector

Deregulation of the labour market, although in the case of agriculture the rules had always been less strict and more difficult to enforce

Freedom of prices

In principle, equilibrium exchange rates

Reduction of tariff rates and application of a uniform rate, albeit with some exceptions, especially for agricultural products

Elimination of taxes and other hindrances to exports

Replacement of agrarian reform programmes with purchase through the land market, aided by loans and/or subsidies for small producers; promotion of formal proof of ownership through the issue of official property titles ${ }^{\text {a }}$

Source: Prepared by the author.

${ }^{\text {a }}$ For more details, see Appendix 1 and 2.

agriculture, where economies of scale are often non-existent, nor generally in agroindustry either. In such a case, then, development based on a domestic market which demands quality and is open to external competition is a perfectly legitimate option. ${ }^{5}$

${ }^{5}$ For example: after the Corporación Colombiana Internacional completed its studies on the possibility of selling tropical fruit on foreign markets it was discovered that the domestic market in Colombia had an unsatisfied demand for such products which was three or four times greater than the external potential estimated in those studies (IICA, 1996).

In the 1990s, in addition to the efforts made to liberalize markets and open up the economies to the exterior, progress has also been made towards decentralization; new arrangements for consultation and participation; incentives for concerted action by different agents; new forms of association between the State and private agents; the transfer of functions from the State to private agents or non-governmental organizations, and the promotion of horizontal policies (the improvement of general education, for example) rather than sectoral ones. 
As a result, the public machinery for agriculture and the rural environment is currently in the midst of a process of change, redefinition and justification of its areas of action and review of its relations with civil society, whereby the latter changes from being a mere beneficiary to an important actor, and like the other areas of government it is striving to increase its efficiency. In order for civil society to become a main actor, however, it must first fulfill a number of requisites: a matter to which we will return later.

Generally speaking, the State has reduced its activities. As a result, in the area of agriculture -which is marked by high risk and the great geographical dispersion of its agents- a number of gaps have arisen which have not yet been filled by the private sector and will not be filled by it in the future unless compensation is provided in unprofitable areas. These gaps have had adverse effects, especially for small and medium-sized producers, in such areas as access to credit, technical assistance for agriculture, markets and collection centres, and also in research aimed at the genetic improvement of seeds and the whole range of technologies designed to aid agriculture using limited resources and marginal land. Non-governmental organizations, within their specialized fields and in keeping with the guidelines laid down by the bodies which finance them, have filled some of the gaps left by the State, but their activities, which are generally on a small scale and are highly localized, have given rise to problems of coordination, feedback and dissemination which are even greater than when rural development was the responsibility of various departments of the State.

In a highly simplified and summary manner, table 1 outlines the main features of the changes which have taken place in agricultural policy.

\section{IV}

\section{The expected results, and those actually obtained}

In theory, the policies of adjustment, liberalization of domestic markets and external openness (which also meant the elimination of the heavy duties levied on agriculture) should generate higher growth rates for the sector as a whole than those registered in the past (3\% per year between 1950 and 1980, and $3.5 \%$ between 1970 and 1980). They should also lead to the redirection of resources to make better use of the comparative advantages of the region (weakened however by the intervention policies of the developed countries). All this should give a strong boost to export agriculture at the expense of the basic grains and relatively non-tradeable goods (products with excessively local consumption patterns, or too perishable, or whose prices do not make up for transport costs) which form the bulk of traditional peasant farming production.

Fifteen years after the initiation of the economic reform processes (although in the agricultural sector in many countries these only began in the 1990s), it may be said that production is indeed being restructured in the expected direction (figure 1), but this process had already begun in the $1970 \mathrm{~s}$, that is to say, before the reforms. A number of other effects of the reform processes are not yet clear. What is clear is that so far the aggregate economic results of the sector have been less encouraging than was hoped for by those who promoted the reforms.

Thus, although the crisis of the 1980s did not hit agriculture as hard as the rest of the economy, the average annual growth rates of the sector (like those of the economy as a whole) have not yet fully recovered: average annual growth between 1991 and $1997^{6}$ was only $2.5 \%$, with big fluctuations from one year to another (table 2).

The volume of agricultural exports grew relatively strongly (3.1\% per year) between 1980 and 1996, but their value increased only slightly up to 1993 because of the decline in international prices. Over the whole period, the annual growth rate of the value of exports was $2.1 \%$ (figure 2 ). The share of

\footnotetext{
${ }^{6}$ Between 1990 and 1995 there were big improvements in average yields, which increased by $3.3 \%$ per year compared with only $1.3 \%$ per year in the $1980 \mathrm{~s}$, but the area cultivated, which had expanded in the 1980 s, went down by $2.2 \%$ per year (FAO, 1996, p. 170).
} 
TABLE 2

Latin America and the Caribbean (23 countries): Gross domestic product of agriculture, forestry, hunting and fishing, and total GDP less GDP of agriculture, forestry, hunting and fishing ${ }^{a}$

(Annual growth rates on the basis of figures in dollars at current prices)

\begin{tabular}{|c|c|c|c|c|c|c|c|c|c|c|c|c|c|c|c|}
\hline \multicolumn{8}{|c|}{ Annual growth rate 1971-1980 above average } & \multicolumn{8}{|c|}{ Annual growth rate 1971-1980 below average } \\
\hline & $\begin{array}{l}1991- \\
1997\end{array}$ & $\begin{array}{l}1091- \\
1990\end{array}$ & $\begin{array}{l}1971- \\
1980\end{array}$ & & $\begin{array}{l}1991- \\
1997\end{array}$ & $\begin{array}{c}1981- \\
1990\end{array}$ & $\begin{array}{c}1971- \\
1980\end{array}$ & & $\begin{array}{l}1991- \\
1997\end{array}$ & $\begin{array}{c}1981- \\
1980\end{array}$ & $\begin{array}{l}1971- \\
1980\end{array}$ & & $\begin{array}{c}1991- \\
1997\end{array}$ & $\begin{array}{c}1981- \\
1990\end{array}$ & $\begin{array}{c}1971- \\
1980\end{array}$ \\
\hline Ecuador & $\begin{array}{c}3.2 \\
(3.6)\end{array}$ & $\begin{array}{c}4.2 \\
(1.4)\end{array}$ & 3.0 & $\begin{array}{l}\text { Dom. } \\
\text { Repub. }\end{array}$ & $\begin{array}{c}4.0 \\
(4.8)\end{array}$ & $\begin{array}{c}0.4 \\
(2.9)\end{array}$ & 3.4 & Chile & $\begin{array}{c}5.0 \\
(8.2)\end{array}$ & $\begin{array}{c}5.6 \\
(2.8)\end{array}$ & 2.2 & Guyana & $\begin{array}{c}9.5 \\
(6.6)\end{array}$ & $\begin{array}{c}-2.5 \\
(-3.1)\end{array}$ & 0.9 \\
\hline Brazil & $\begin{array}{c}3.0 \\
(3.0)\end{array}$ & $\begin{array}{c}2.5 \\
(1.5)\end{array}$ & 4.7 & Bolivia & $\begin{array}{c}3.7 \\
(4.2)\end{array}$ & $\begin{array}{c}1.7 \\
(-0.1)\end{array}$ & 4.1 & Peru & $\begin{array}{c}4.8 \\
(5.6)\end{array}$ & $\begin{array}{c}2.2 \\
(-1.4)\end{array}$ & -0.6 & Uruguay & $\begin{array}{c}4.2 \\
(4.1)\end{array}$ & $\begin{array}{l}0.2 \\
(-)\end{array}$ & 0.6 \\
\hline \multirow[t]{3}{*}{ Paraguay } & $\begin{array}{c}2.5 \\
(2.8)\end{array}$ & $\begin{array}{c}4.0 \\
(2.7)\end{array}$ & 6.7 & $\begin{array}{l}\text { Guate- } \\
\text { mala }\end{array}$ & $\begin{array}{c}2.8 \\
(4.5)\end{array}$ & $\begin{array}{c}1.3 \\
(0.8)\end{array}$ & 4.7 & Nicaragua & $\begin{array}{c}4.5 \\
(1.8)\end{array}$ & $\begin{array}{c}2.9 \\
(-1.8)\end{array}$ & -0.1 & Jamaica & $\begin{array}{c}2.6 \\
(0.1)\end{array}$ & $\begin{array}{c}0.9 \\
(2.3)\end{array}$ & 0.9 \\
\hline & & & & & & & & Honduras & $\begin{array}{c}3.4 \\
(3.8)\end{array}$ & $\begin{array}{c}2.7 \\
(2.3)\end{array}$ & 2.7 & Argentina & $\begin{array}{c}2.4 \\
(5.7)\end{array}$ & $\begin{array}{c}1.3 \\
(-0.9)\end{array}$ & 2.1 \\
\hline & & & & & & & & $\begin{array}{l}\text { Costa } \\
\text { Rica }\end{array}$ & $\begin{array}{c}2.6 \\
(3.6)\end{array}$ & $\begin{array}{c}3.1 \\
(2.1)\end{array}$ & 2.6 & & & & \\
\hline Venezuela & $\begin{array}{c}1.5 \\
(3.4)\end{array}$ & $\begin{array}{c}2.0 \\
(-0.9)\end{array}$ & 2.9 & Mexico & $\begin{array}{c}1.6 \\
(2.9)\end{array}$ & $\begin{array}{c}1.2 \\
(1.9)\end{array}$ & 3.4 & Panama & $\begin{array}{c}1.6 \\
(5.1)\end{array}$ & $\begin{array}{c}2.9 \\
(1.2)\end{array}$ & 1.3 & $\begin{array}{l}\text { Trin.and } \\
\text { Tobago }\end{array}$ & $\begin{array}{c}1.5 \\
(2.5)\end{array}$ & $\begin{array}{c}0.1 \\
(-2.7)\end{array}$ & -3.0 \\
\hline \multirow[t]{3}{*}{ Colombia } & $\begin{array}{c}1.4 \\
(4.6)\end{array}$ & $\begin{array}{c}3.0 \\
(3.9)\end{array}$ & 4.4 & & & & & & & & & $\begin{array}{l}\text { El Sal- } \\
\text { vador }\end{array}$ & $\begin{array}{c}1.2 \\
(6.0)\end{array}$ & $\begin{array}{c}-1.4 \\
(-0.2)\end{array}$ & 2.4 \\
\hline & & & & & & & & & & & & Barbados & $\begin{array}{l}-1.2 \\
(0.9)\end{array}$ & $\begin{array}{l}-0.2 \\
(1.3)\end{array}$ & -1.1 \\
\hline & & & & & & & & & & & & Haiti & $\begin{array}{c}-6.4 \\
(-1.4)\end{array}$ & $\begin{array}{c}-0.2 \\
(-0.7)\end{array}$ & 1.5 \\
\hline
\end{tabular}

Source: Prepared on the basis of figures provided by the ECLAC Statistical Division.

a The shaded figures correspond to agricultural GDP growth higher than the average for the region as a whole (excluding Brazil) and the figures in parentheses correspond to the annual growth rate of GDP in constant dollars, less the agricultural GDP.

Average annual growth rates of agricultural GDP of the region:

$\begin{array}{ccc} & \text { Without Brazil } & \text { With Brazil } \\ 1991-1997 & 2.3 & 2.5 \\ 1981-1990 & 1.8 & 2.0 \\ 1971-1980 & 2.9 & 3.5\end{array}$

Average annual growth rates of total GDP less agricultural GDP

$\begin{array}{ccc} & \text { Without Brazil } & \text { With Brazil } \\ 1991-1997 & 4.1 & 3.7 \\ 1981-1990 & 0.9 & 1.1\end{array}$

non-traditional products (such as tropical or temperate fresh fruit and vegetables) in agricultural exports has increased, and they now account for nearly $25 \%$ of such exports. In terms of the area planted and the number of jobs generated, however, non-traditional exports are much less important.

Agricultural imports, in contrast, which had gone down sharply between 1981 and 1987 (-5.8\% per year in terms of value), thereafter resumed the rapid growth begun in the mid-1970s (12.1\% per year in value between 1987 and 1996). They consist mainly of staple foodstuffs such as cereals and dairy products. Over the period from 1980 to 1996, agricultural imports grew at an overall annual rate of $3.0 \%$ in volume and $3.9 \%$ in value.
In the economy as a whole, growth since the beginning of the 1990s has been based on relatively intensive use of capital and has created little employment; the difference between the wages of the most highly skilled workers and the unskilled has increased, as also has the gap between rich and poor. Generally speaking, the model seems exclusive for a substantial segment of the population and also for the agricultural sector (table 3). Contrary to what has occurred in urban areas, in rural areas the levels of poverty and indigence after the crisis seem to have stuck at high levels: $54 \%$ and $31 \%$ of rural households or 78.2 and 47.0 million persons, respectively, in 1997 (ECLAC, 1999). 
FIGURE 1

Latin America and the Caribbean: Changes in the structure of production

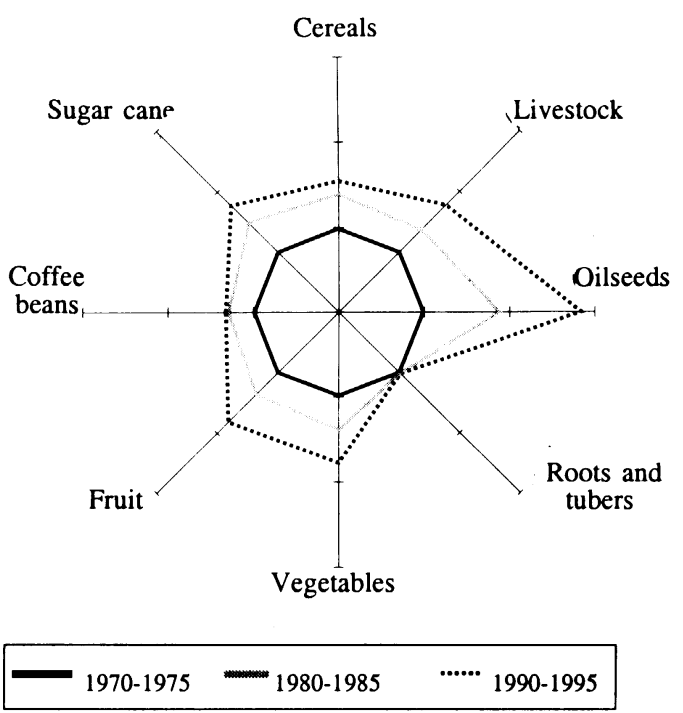

Source: ECLAC/IICA (1997), with data from the United Nations Food and Agriculture Organization (FAO).
FIGURE 2

Latin America and the Caribbean:

Agricultural trade

(Base 1989-1991 = 100)

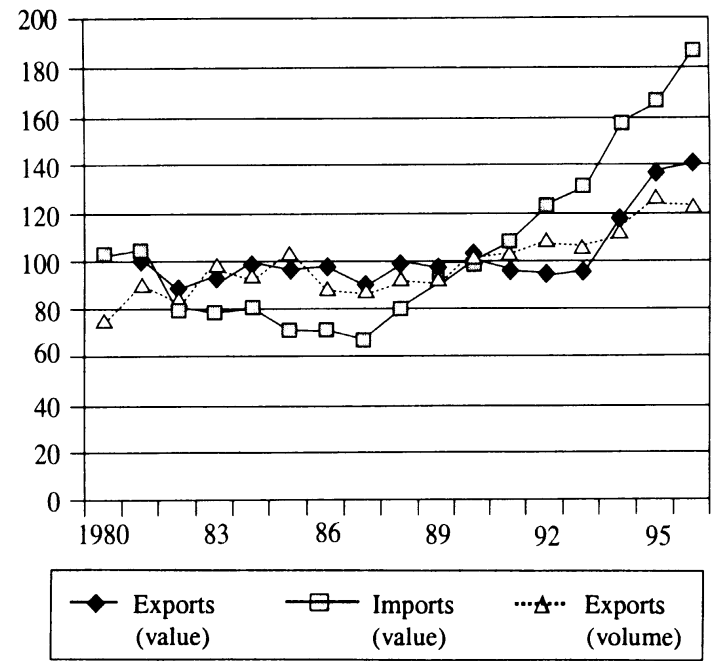

Source: FAO-Internet, December 1998.

TABLE 3

Latin America: Changes in the structure of agricultural production, 1970-1995

\begin{tabular}{|c|c|c|c|c|c|}
\hline Product & Sector A & Sector B & Area & Productivity & Labour intensity \\
\hline Oilseeds & $\mathrm{X}$ & & Greatly increased & Greatly increased & Low intensity \\
\hline Cereals & $\mathrm{X}$ & & Increased & Greatly increased & Low intensity \\
\hline Cereals & & $X$ & Went down & Remained unchanged & Medium intensity \\
\hline Fruit and vegetables & $\mathrm{X}$ & $\mathrm{X}$ & Increased & Increased & Intensive \\
\hline Stock-raising (for meat) & $\mathrm{X}$ & $\mathrm{X}$ & Increased & Increased somewhat & Low intensity \\
\hline Stock-raising (for milk) & $\mathrm{X}$ & $\mathrm{X}$ & Increased & Increased & Intensive \\
\hline Small livestock (poultry, pigs) & $\mathrm{X}$ & & Very small & Increased & Intensive \\
\hline Tubers and pulses & & $\mathrm{X}$ & Remained unchanged & Remained unchanged & Medium intensity \\
\hline Artificial forests & $\mathrm{X}$ & & Increased somewhat & Increased & Low intensity \\
\hline Natural forests & & $\mathrm{X}$ & Went down & Remained unchanged & - \\
\hline
\end{tabular}

Source: Prepared by the author.

a Sector A: mainly modern

Sector B: mainly traditional. 


\section{V}

\section{Interpretation of the somewhat disappointing performance of agriculture}

It is important to note that the promoters of the reforms had identified serious hindrances to development -especially for the agricultural sector- in the previous model and were expecting that the reforms would bring more dynamic growth than in the past.

In order to understand why the performance was lower than expected, ${ }^{7}$ it should be borne in mind that the countries applied adjustment, free-market and economic openness measures of different intensities, spread over time in different manners, ${ }^{8}$ with a number of exceptions for the agricultural sector. In a number of countries the markets only began to be liberalized at the end of the 1980s or even later (figure 3), while others, after a short spell of liberalization, reintroduced tariffs and support measures for prices and domestic sales. ' Indeed, many of the changes in agricultural policy, rather than forming part of a well-defined development strategy, were in the nature of special measures taken in response to short-term macroeconomic or sectoral problems and demands by pressure groups.

The trade negotiations did not fit in with clear strategies either, and the consolidated levels agreed

\footnotetext{
${ }^{7}$ ECLAC is carrying out two interdisciplinary projects of broad scope in order to analyse whether it was the theory or its manner of application which went wrong, or if it is too early as yet to see all the benefits of the reforms. Here we will merely outline the explanations that would appear to be applicable with regard to the agricultural sector.

${ }_{9}^{8}$ See, for example, Ramos (1997).

${ }^{9}$ This occurred, for example, in Chile (with the reintroduction of government purchasing programmes after the 1982 crisis and the introduction of official price ranges), while Colombia introduced or reintroduced measures such as minimum import prices, compulsory prior licences, a stabilization fund for cotton, a more active role for the reception stations of the Agricultural Marketing Institute (IDEMA), the restoration of lines of credit, a rescue operation for the Caja Agraria bank, a technological shock plan and agricultural insurance. José Antonio Ocampo, who was Minister of Agriculture of Colombia in 1993, justified these measures because of the great economic and above all social importance of the sector and also because, as he said, "the idea that the mere lowering of levels of protection for agriculture as a whole was all that was necessary in order to make the sector flourish has been a failure" (Colombia, Ministry of Agriculture, 1993, pp. 3-7.
}

FIGURE 3

Latin America (9 countries):

Changes in average tariffs for foodstuffs

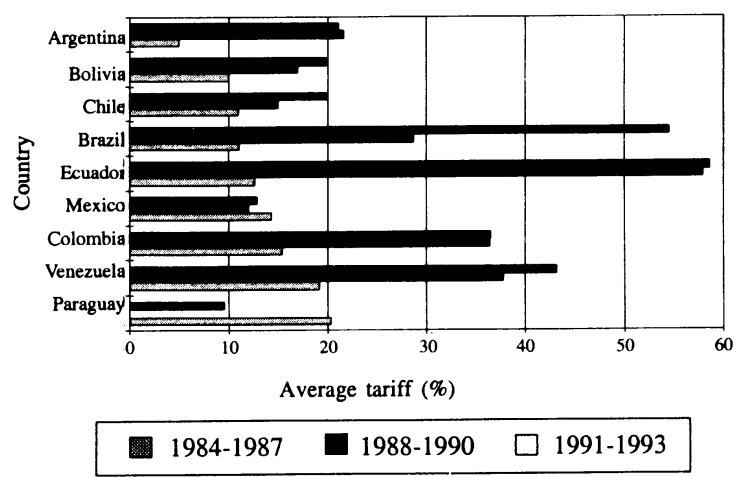

Source: ECLAC/IICA (1997), on the basis of data from the United Nations Conference on Trade and Development (UNCTAD).

upon in the Uruguay Round (the theoretical tariff) resulted in great dispersion, even between countries with bilateral or multilateral agreements, and did not form a complete structure of corrective duties to make up for the unequal conditions of competition. ${ }^{10}$

Furthermore, during much of the last 15 years the efforts to secure greater openness have coincided with a depressed world market, with (in most of the countries of the region) exchange rates that were first over-devalued and then over-revalued, ${ }^{11}$ more expen-

\footnotetext{
${ }^{10}$ An example of this is the Andean countries, which have a common external tariff (between 15\% and 20\%), supplemented with price ranges or flexible tariffs for a number of agricultural products. However, Colombia negotiated consolidated tariffs ranging from $15 \%$ to $332 \%$, with an average of $118 \%$; Ecuador negotiated an average tariff of $26 \%$; Venezuela consolidated its tariffs for most agricultural products at $40 \%$, but with some special tariff ranges which brought the average up to $59 \%$; and Bolivia consolidated its tariffs at a uniform $40 \%$ : i.e., three times the normal tariff (IICA, 1996).

${ }^{11}$ If we compare the real exchange rate prevailing in 1996 with that of 1990, we see that it rose and hence favoured exports in only six countries: Bolivia, Honduras, Nicaragua, Paraguay, Costa Rica (up to 1995) and Mexico (in 1994 and 1995). In all the other countries it went down (ECLAC/IICA, 1997, on the basis of ECLAC data).
} 
sive and restricted credit, ${ }^{12}$ and a decline in per capita income which led to lower domestic consumption of agricultural products and a shift towards cheaper products, often provided by traditional agriculture (such as cereals, dried pulses and roots and tubers). Together, all these factors probably held back the expected restructuring of the more modern sector. The lower use of various State services and their only partial replacement by equivalent or better private services, together with the limited adaptation capacity of the traditional peasant sector (because of lack of resources, lack of information and excessive risks), also probably held back possible changes in the sector, except for some successful examples of vertical coordination with agribusiness, especially for export. In this context, the reforms have tended to cause tensions between farmers and the authorities which -as in the developed countries- have often been settled through the reintroduction of protectionist measures.
Thanks to policies aimed at greater trade openness and the development registered in infrastructure, agricultural production has become more internationally tradeable and the price of the products depends less and less on micro-regional and national supply and demand (or tariff and price policies) and more and more on variations in external supply and demand. The regulatory effect on producers' income exerted in the past by rises (or falls) in prices due to bad (or plentiful) local harvests is less and less noticeable. In the face of this growing exposure to international prices, the agricultural sector will be able to sustain itself if: i) it manages to produce at internationally competitive prices and to create mechanisms for reducing risks (or offering sufficiently high income to offset them) and for keeping own-account producers, employers and wage-earners in business, and ii) it can attract the investments needed to continue being competitive on the international and also the domestic level.

\section{VI}

\section{Some additional interpretations}

So far, the interpretation made of the reasons for the performance registered by agriculture has been of a rather traditional nature. We will now explain why we feel that a number of the innovations made in policies for the sector will tend to be exclusive unless they are accompanied by measures to boost the sector's functioning.

\section{The agents and the actual agricultural and rural situation in the region}

A very rough calculation of the economically active population (EAP) of the region indicates that there are some 17 million agricultural producers -employers and own-account workers- out of a total agricultural EAP of some 41 million persons. These producers are the economic agents who are expected

\footnotetext{
12 If we compare the real interest rate prevailing in 1996 with that of 1992, we see that it went down in Chile, Honduras, Panama, Peru, Venezuela, Brazil (as from 1994) and Costa Rica (as from 1993), but in all the other countries it went up (ECLAC/IICA, on the basis of ECLAC data).
}

to respond to policy stimuli. We will leave aside the 3 million employers (who should have a greater response capacity one way or another because they have more capital and probably more training) and concentrate on the 14 million own-account agricultural workers (figure 4 and table 4). According to poverty statistics (ECLAC, 1999), the percentage of poor among these own-account workers is similar to that of the rural population as a whole, so that roughly $55 \%$ of these 14 million are below the poverty line (and a third of them may also be below the indigence line), with everything that that implies in terms of capacity to accumulate investment resources, to think past the short term, to take risks and innovate and to see agricultural activities as a valid long-term option.

If we also add the lack of schooling (which is even more marked among the decision-makers, that is to say, those over 40-50 years of age), the flaws and asymmetrical aspects of the information market, and the ever-increasing requirements of a flexible, open and globalized market, it is easy to understand why such an important group of agents is at a serious 
FIGURE 4

Latin America: Economically active population, 1995

\begin{tabular}{|c|c|c|c|c|c|c|}
\hline \multicolumn{7}{|c|}{$\begin{array}{c}\text { TOTAL EAP } \\
189 \text { million } \\
100 \%\end{array}$} \\
\hline \multicolumn{3}{|c|}{$\begin{array}{c}\text { URBAN } \\
142 \text { million } \\
75 \%\end{array}$} & \multicolumn{4}{|c|}{$\begin{array}{l}\text { RURAL } \\
47 \text { million } \\
25 \%\end{array}$} \\
\hline Non-agricultural & \multicolumn{2}{|c|}{ Agricultural } & \multicolumn{3}{|c|}{ Agricultural } & Non-agricultural \\
\hline $\begin{array}{c}134 \text { million } \\
94 \% \\
\end{array}$ & \multicolumn{2}{|c|}{$\begin{array}{c}8 \text { million } \\
6 \% \\
\end{array}$} & & \multicolumn{2}{|l|}{$\begin{array}{c}33 \text { million } \\
69 \% \\
\end{array}$} & $\begin{array}{c}14 \text { million } \\
31 \%\end{array}$ \\
\hline & \multicolumn{5}{|c|}{ Agricultural EAP } & \\
\hline & \multicolumn{2}{|c|}{ Urban } & \multicolumn{3}{|c|}{ Rural } & \\
\hline \multirow{4}{*}{$\begin{array}{l}\text { Urban poverty } \\
\qquad 30 \% \\
\text { Indigence } 10 \%\end{array}$} & \multicolumn{2}{|c|}{$\begin{array}{l}8 \text { million } \\
20 \%\end{array}$} & & \multicolumn{2}{|l|}{$\begin{array}{l}33 \text { million } \\
80 \%\end{array}$} & Rural poverty \\
\hline & \multirow{2}{*}{ Employers } & \multicolumn{2}{|c|}{ Wage-earners } & \multirow{2}{*}{ Own-account } & \multirow{2}{*}{$\begin{array}{l}\text { Unpaid family } \\
\text { members }\end{array}$} & Indigence $31 \%$ \\
\hline & & Temporary & Permanent & & & \\
\hline & $\begin{array}{c}3 \text { million } \\
8 \%\end{array}$ & $\begin{array}{l}9 \text { million } \\
22 \%\end{array}$ & $\begin{array}{c}5 \text { million } \\
11 \%\end{array}$ & $\begin{array}{c}14 \text { million } \\
33 \%\end{array}$ & $\begin{array}{l}11 \text { million } \\
26 \%\end{array}$ & \\
\hline
\end{tabular}

Source: Prepared by the author on the basis of CELADE (1995 and 1996), FAO (1994), Klein (1992), household surveys effected in various countries in 1992, and ECLAC (1999).

disadvantage in terms of responding to supposed policy stimuli or is indifferent to them. We use the term "indifferent" because as they do not have access to credit it is all the same to them whether interest rates rise or fall, and if they primarily consume their own production or use mainly domestic inputs and goods they have little direct interest in whether the exchange rate is higher or lower.

Fixed transaction costs and the existence of imperfect markets (especially for land, credit and labour) also explain the apparent lack of reaction to price changes of large groups of agricultural producers constrained by their shortage of resources. The fixed transaction costs (for information, organization and hiring) that must be incurred in order to progress from production for one's own consumption to production for the market can be very high, thus making it necessary to produce a certain minimum quantity even though production itself may be neutral in terms of scale. Furthermore, these fixed transaction costs may not be recoverable through other activities, and if they are very high they would make it necessary to participate in a given market for a number of years in a row. For this reason, producers may decide not to incur such costs unless they are sure of being able to participate in the market for the necessary length of time. Thus, in proportion as participation in the markets is more risky and there are no insurance mechanisms external to the farm, producers will opt to continue with an approach based on food self-sufficiency longer than would appear to be warranted by the size of transaction costs. This is why even small producers who participate actively in the markets tend to continue producing crops for their own consumption (De Janvry and Sadoulet, 1998).

\section{The explicit and implicit assumptions behind the new sectoral policy approaches}

We will now deal with several of the policies outlined in table 1 , formulating our reservations in respect of each of them. 
Latin America in the 1990s: The real agricultural and rural situation in figures

\begin{tabular}{|c|c|c|c|c|c|c|c|c|c|c|c|}
\hline & $\begin{array}{l}\text { Latin } \\
\text { America }\end{array}$ & $\begin{array}{l}\text { Argen- } \\
\text { tina }\end{array}$ & Bolivia & Brazil & Chile & $\begin{array}{l}\text { Colom- } \\
\text { bia }\end{array}$ & $\begin{array}{l}\text { Costa } \\
\text { Rica }\end{array}$ & Jamaica & Mexico & Peru & $\begin{array}{l}\text { Vene- } \\
\text { zuela }\end{array}$ \\
\hline \% agricultural EAP/total EAP (1994) & 23.9 & 9.4 & 39.4 & 21.9 & 11.2 & 24.7 & 21.4 & 25.4 & 27.5 & 32.6 & 9.4 \\
\hline$\%$ agricultural GDP/total GDP (1997) & 7.6 & 6.6 & 14.9 & 6.9 & 6.8 & 13.5 & 14.9 & 7.6 & 6.6 & 7.0 & 4.8 \\
\hline $\begin{array}{l}\% \text { agricultural exports (including forestry, } \\
\text { fisheries and processed products)/total exports }\end{array}$ & 26 & 55 & 28 & 35 & 39 & 38 & 69 & & 9 & 32 & 4 \\
\hline $\begin{array}{l}\text { Agricultural GDP in } 1997 \text { (millions of } \\
1990 \text { dollars) }\end{array}$ & 103656.3 & 13513.4 & 1033.8 & 36471.7 & 3519.0 & 7196.3 & 1080.4 & 298.3 & 21070.2 & 3654.8 & 2903.4 \\
\hline Agricultural EAP (thousands, 1994) & 41000 & 1148 & 931 & 13110 & 571 & 2885 & 251 & 319 & 9016 & 2554 & 719 \\
\hline $\begin{array}{l}\text { Productivity of agricultural EAP in } 1994 \\
\text { (in constant } 1990 \text { dollars) }\end{array}$ & 2528 & 11033 & 1009 & 3504 & 5320 & 2415 & 4186 & 1043 & 2189 & 1253 & 3878 \\
\hline $\begin{array}{l}\text { Annual growth rate of agricultural EAP } \\
(1980-1993)\end{array}$ & 0.4 & -1 & 1.2 & -0.3 & -0.3 & 0.4 & 0.4 & 0.6 & 1 & 1.2 & -0.7 \\
\hline Agricultural employers (thousands) & 3000 & & & 643.5 & 39.9 & & 13.5 & & 1205.5 & & 105.2 \\
\hline $\begin{array}{l}\text { Own-account agricultural producers } \\
\text { (thousands) }\end{array}$ & 14000 & & & 4263.3 & 192.7 & & 54.2 & & 2737.4 & & 217.7 \\
\hline $\begin{array}{l}\% \text { of poor among own-account } \\
\text { agricultural producers }{ }^{b}\end{array}$ & & & 89 & 56 & 20 & 67 & 24 & & 68 & & 44 \\
\hline $\begin{array}{l}6 \text { or more years of formal schooling } \\
\text { (\% of total } 15-24 \text { group) }\end{array}$ & & & & 29 & 88 & 47 & 82 & & 80 & & \\
\hline $\begin{array}{l}6 \text { or more years of formal schooling } \\
\text { (\% of total } 25-59 \text { group) }\end{array}$ & & & & 15 & 60 & 25 & 70 & & 48 & & \\
\hline $\begin{array}{l}\text { Average size of farms (hectares) } \\
\text { Number of farms of less than }^{c}\end{array}$ & 60.9 & 469.0 & & 64.7 & 94.1 & 26.3 & 40.6 & & 24.6 & 18 & 82.6 \\
\hline 5 hectares (thousands) $^{\mathrm{c}}$ & & 57.0 & & 2977.5 & 134.3 & 700.2 & 35.2 & & 2620.4 & 1026.2 & 169.7 \\
\hline$\%$ of farms of less than 5 hectares ${ }^{c}$ & 47.5 & 15.1 & & 39.7 & 42.5 & 59.5 & 45.8 & & 59.4 & 78.0 & 44.8 \\
\hline $\begin{array}{l}\text { Arable land/agricultural EAP (hectares } \\
\text { per person, 1993) }\end{array}$ & 3.0 & 21.6 & 2.3 & 3.2 & 7.0 & 1.4 & 1.1 & 0.5 & 2.6 & 1.3 & 4.5 \\
\hline $\begin{array}{l}\text { Arable land/tractors in use } \\
\text { (hectares per tractor, 1993) }\end{array}$ & 80.8 & 89.3 & 396.3 & 57.1 & 95.5 & 107.4 & 40.7 & 50.3 & 134.6 & 206.1 & 65.6 \\
\hline $\begin{array}{l}\text { Agricultural GDP in 1996/hectares of } \\
\text { arable land (in } 1990 \text { dollars) }\end{array}$ & 948 & 527 & 464 & 1184 & 819 & 1874 & 3819 & 2266 & 901 & 1042 & 872 \\
\hline
\end{tabular}

Source: Dirven (1997), ECLAC/IICA (1997), ECLAC (1999), and ECLAC, Statistics and Projections Division, computerized tables (March 1998).

${ }^{a}$ Approximate values for 1995 .

b Including agriculture, stock-raising, fisheries, hunting and forestry; data for 1996 or 1997, except in the case of Venezuela, where the data are for 1994.

${ }^{\mathrm{c}}$ Data taken from agricultural censuses (various years). 
i) Political and financial decentralization designed to further local projects. In order to implement this approach, the agents must have: sufficient organizational capacity and political weight for their demands to be heard; capacity to formulate their demands in the required formats, types of content and time limits; and capacity to supervise and control regional action. Experience shows that many agricultural producers lack these capabilities and have no access to the training needed in order to acquire them. ${ }^{13}$

ii) Investments in infrastructure and services based on the demand of the beneficiary population and co-financing. Because of low geographical density, rural infrastructure and services are generally more expensive per unit of benefit and beneficiary, and many of the latter have little or no payment capacity.

iii) Demand-oriented and co-financed research in both research institutes and universities. The situation observed here is one of relative neglect of basic research, with greater emphasis on shorter-term and directly applicable research projects, a shift from staple products to non-traditional products with greater added value, and some divergence between the international research centres, which continue to be oriented towards research on staple foods, and the national research centres, which seek to meet the needs of the more dynamic producers.

iv) Elimination of free State technical assistance and its replacement by paid private technical assistance. The latter is provided in response to demand from producers and, when accompanied by a subsidy, after presentation of a project in a competition. The problems arise because of the lack of payment capacity of some producers; unsatisfactory capacity to formulate projects for competition in the required formats; inadequate dissemination and socialization of the experience gained; failure to comply with deadlines and lack of continuity of efforts; lack of interest of consultants in travelling to more distant

\footnotetext{
${ }^{13}$ See Durston (1999) on ways of promoting the acquisition of these capabilities.
}

places or carrying out more complex and higher-risk projects; and insufficient capacity for the evaluation of proposals and control of projects by the authorities which co-finance or subsidize the projects.

v) Elimination of specific lines of credit for the agricultural sector. The agricultural sector is less attractive to credit institutions than other sectors of the economy both because of the inherently high risks in its activities (risks due to the weather, phyto-sanitary factors and sharp fluctuations in prices) and the insufficient means for reducing these risks (insurance, stabilization funds, futures), and because of the heavy indebtedness of many farmers and their geographical dispersion. According to partial information from a number of countries of the region, ${ }^{14}$ credit for the agricultural sector has gone down substantially since the reforms, especially for small and medium-sized producers.

vi) Replacement of agrarian reform programmes by purchases made through the land market, with the aid of credit and/or subsidies for small producers. Efforts to determine whether the desired objectives are being achieved by this means have only begun recently. According to some studies ${ }^{15}$ made in Mexico and Peru (both of which made a thorough-going review of the laws governing the land market in the early 1990s), the market for both the rental and the sale or purchase of land is generally sluggish but tends towards the concentration of ownership in the categories of medium and large landowners.

It would therefore appear that while the policies applied are outwardly neutral, in reality they are often highly exclusive because they do not take account of the special features of the agricultural sector, the serious shortcomings in a number of its markets, the high transaction costs which prevail, or the lack of physical, financial, human and social capital among many of its agents. The results of these policies are nevertheless considered politically and morally justified because they are "responses to demand".

\footnotetext{
${ }^{14}$ Including Brazil, Costa Rica, Mexico and Peru (the information is based on presentations and as yet unpublished documents presented at the seminar on the impact of structural reforms on agriculture in Latin America, organized by ECLAC at Santiago, Chile, from 25 to 27 November 1998).

${ }^{15}$ Carried out in 1997 and 1998 under an ECLAC/FAO project in the first case and an ECLAC/GTZ project in the second.
} 


\section{VIII}

\section{Conclusions}

The available information indicates that in the 1990s the growth rate of agricultural production has been below its historical level and agricultural exports have grown a good deal more slowly than agricultural imports. Furthermore, there are more and more indications that modernization and increases in yields have been concentrated among a limited number of farmers, while the others have not shared in this progress or have even suffered setbacks.

In our opinion, the fact that large groups of producers are not forming part of the growth processes that -according to the advocates of the reformsshould have begun with the policy reorientation measures is due to a lack of realism: insufficient account was taken of the special features of the agricultural sector and the disadvantages of its agents. This lack of response by a major group of agents would appear to be the reason why, in aggregate terms, the sector has turned in a rather mediocre performance.

Can there be dynamic rural development without the incorporation of this group into new forms of production? Can there be dynamic, balanced and equitable national development with the exclusion that stems from the policies studied here? What are the alternatives, and the costs and benefits of the different options?

The answers to these questions are not easy, especially as there seems to be little room for sectoral and regional actions in a model governed by the market.

The persistence of rural poverty has given rise to policies of investment in infrastructure and services (especially health and education) which are undoubt- edly very necessary and -along the lines suggested by De Janvry and Sadoulet (1998)- should help to reduce transaction costs to some extent and hence allow a larger group of agents to participate profitably in the market.

Another response has been to divide up the poor sector of the rural population between those whose assets are considered sufficient to give them a chance of overcoming poverty through improvements in their production, trade or organization and those who are deemed to require help through social policies. As long as the persons in this latter category only form a relatively small proportion of the total population or of the population of a particular region, this position can be justified from the economic point of view, although not necessarily from the point of view of development in general and still less from that of human and social capital formation. But what should we do if these persons represent a high proportion of the total population? How can we foster a virtuous circle of agricultural or non-agricultural productive activities, in a reasonable length of time and at reasonable cost, in areas with relatively scanty natural resources and underdeveloped physical and human capital $^{16}$

The truth is that even if there were a political and conceptual framework that permitted more decided action in this respect it would still not be clear whether it is possible to induce such a virtuous circle, or how. It is very necessary that future efforts to develop new technical approaches and concrete practical proposals should seek the answers to these questions.

(Original: Spanish)

\footnotetext{
${ }^{16}$ This latter concern arose, among other reasons, as a result of repeated conversations on the subject with Maximiliano Cox, Regional Adviser of ECLAC, and also with Julio Berdegué, Director of the International Network on the Methodology of Production Systems Research (RIMISP).
} 
APPENDIX 1

\section{Latin America: Evolution of national \\ agricultural innovation institutes (INIA)}

1960: The "Green Revolution" technological package is distributed as a public good.

1970: The budgetary allocations for INIAs are increased and their staffs grow.

1980: The crisis of the 1980s severely affects the financing of INIAs. By the end of the decade, all of them are affected by the effects of the crisis and of the adjustment programmes.

In addition to these budget cuts, financial resources for agricultural research provided by international agencies and donor countries are also reduced.

1990: Reforms are begun in almost all the INIAs of the region, in an environment marked by relative shortage of funds for research, growing appropriability of technology, and the emergence of new demands posed to the INIAs. The latter are mainly the result of the intensive processes of urbanization (demand for post-harvesting technologies) and the processes of greater openness and deregulation (technologies and processes for increasing value added, improving competitiveness and developing the production of non-traditional agricultural exports).

On another level, the demands for a more prominent role for the private sector are reflected in reforms in the organization and statutes of the INIAs.

New forms of financing appear, such as foundations for technological research and transfer and funds available through competitions.

The main INIAs of the region recover from the point of view of fiscal budget allocations and also markedly increase the generation of resources of their own.
The establishment of INIAs is begun in most of the countries of the region, and existing INIAs are further strengthened.

The INIAs obtain excellent results in fulfilling their mission, as shown by all the impact evaluation studies made.

The INIAs enter into a crisis: in a first stage, their manning tables continue to grow by inertia, while their financing is reduced, so that there are fewer resources for research and fewer resources per researcher.

Towards the end of the decade, a number of institutes drastically cut their staff, including even the most highly qualified staff members, while others reduce their manning tables and payrolls.

The reforms are basically as follows:

a) Research programmes in line with the clients' demands are established and agricultural producers and representatives of the private sector are brought into their governing councils.

b) Programmes connected with poverty and extreme poverty and preservation of natural resources and the environment begin to be given priority, largely at the request of international agencies.

c) In many INIAs priority is given to the development of processes and technologies for improving competitiveness, post-harvesting technologies and biotechnology. Programmes are established for agroindustry and the development of non-traditional export crops.

d) In order to secure greater efficiency in the management of budgetary resources, outlays considered to be less important are reduced and various services are outsourced.

e) The INIAs increase the generation of resources of their own, through the sale of goods and services and even by selling off assets.

Research and the transfer of technology are regionalized as a way of making them more efficient and bringing the institutions closer to their clients.

Source: César Morales, ECLAC, on the basis of information from the various INIAs. 
APPENDIX 2

Recent changes in land tenure legislation

Country, law and objective

Bolivia, 1996. Law on the National Agrarian Reform Service.

Objective: to increase the equity and security of land tenure.

Colombia, 1994. Law No. 160, setting up the National Agrarian Reform and Rural Development System. Objective: to facilitate access of poor peasants to land.

Mexico: 1992. Amendment to article 27 of the 1917 Constitution.

Objective: eliminating hindrances to development.

Peru, 1991, 1992 and 1995. Agrarian Law.

Objective: to expand and strengthen private property rights.
Main features of the law

Members of the indigenous population have preferential access to public lands.

Process of clearing land ownership titles over a period of ten years.

Land tax.

The beneficiaries of the programme are responsible for negotiating the purchase of land directly with its owner. The State gives a direct subsidy of up to $70 \%$ of the purchase price.

The remaining $30 \%$ can be financed with long-term State credit.

The government is no longer obliged to provide land to all who ask for it. Communal landowners ("ejidatarios") can become private owners and sell, rent, sharecrop or mortgage their property.

Ejidatarios are no longer obliged to work their land themselves.

Size limits are maintained (100 hectares of irrigated land).

Commercial companies can acquire land.

Authorization to sell or mortgage land obtained under the agrarian reform process.

Authorization for issue of individual titles to communal land, subject to the agreement of over $50 \%$ of the communal owners.

Size limits are maintained (1000 hectares).

Commercial companies can acquire land.

\section{Strengthening of institutions}

Land inventory and register, administered at the municipal level.

System for the settlement of problems.

Restructuring of the National Agrarian Reform Institute to adapt it to its new role of facilitating and supervising land transactions.

Establishment of local Agrarian Tribunals to settle disputes over property rights.

Establishment of the "Procaduría Agraria" to watch over the proper application of the law.

Establishment of the National Land Register.

Programme for the certification of ejido rights and issue of ownership titles for urban plots (PROCEDE).

Special project for the issue of official titles to land.

Source: Information provided by Frank Vogelgesang, based on the ECLAC/GTZ project on policies to promote rural land markets. 


\section{Bibliography}

Baer, W. and W. Maloney (1997): Neoliberalismo e distribuição, Revista de economia política, vol. 17, No. 3, São Paulo, Centro de Economia Política, July-September.

Binswanger, H. P. and K. Deininger (1997): Explaining Agricultural and Agrarian Policies in Developing Countries, Policy research working paper No. 1765, Washington, D.C., World Bank.

CELADE (Latin American Demographic Centre) (1995): América Latina: proyecciones de población urbana-rural 1970-2025, Boletín demográfico, No. 56, Santiago, Chile.

(1996): América Latina: población económicamente activa 1980-2025, Boletín demográfico, No. 57, Santiago, Chile.

Colombia, Ministerio de Agricultura (1993): El balance del sector agropecuario en 1993: la política de reactivación y sus frutos, Santafé de Bogotá, December.

De Janvry, A. and E. Sadoulet (1993): Market, State, and civil organizations in Latin America. Beyond the debt crisis: the context for rural development, World Development, vol. 21, No. 4, Oxford, U.K., Pergamon Press.

-(1998): Smallholder integration into markets: determinants of entry and supply response, paper presented at the Third Latin American Symposium on Research and Extension in Agricultural Systems (IESA-AL-III): New Approaches to Overcome Rural Poverty and Develop Local Capabilities, Lima, 19-21 August.

Dirven, M. (1997): El empleo agrícola en América latina $y$ el Caribe: pasado reciente y perspectivas, "Desarrollo productivo" series, No. 43, LC/G.1961, Santiago, Chile, ECLAC.

Durston, John (1999): Construyendo capital social comunitario. Una experiencia de empoderamiento rural en Guatemala, LC/L.1177, United Nations.

ECLAC (Economic Commission for Latin America and the Caribbean) (1995): Reformas económicas en América Latina: una síntesis de la experiencia en once países, LC/R.1606, Santiago, Chile. (1997a): Estrategia de apertura comercial: planteo teórico y evidencias empíricas, LC/R.1732, Santiago, Chile.

- (1997b): La participación organizada en el desarrollo agro-rural del Paraguay, LC/R.1765, Santiago, Chile.

(1999): Social Panorama 1998, LC/G.2050-P, Santiago, Chile.

ECLAC/IICA (Inter-American Institute for Cooperation on Agriculture) (1997): Survey of Agriculture in Latin America and the Caribbean Over Recent Decades (Performance Indicators in Charts and Tables), LC/L.1102, Santiago, Chile.

Edwards, S. (1997): El mal desempeño de las economías latinoamericanas, Estudios Públicos, No. 67, Santiago, Chile, Centro de Estudios Públicos (CEP).

FAO (Food and Agriculture Organization of the United Nations) (1994): Yearbook. Production 1994, Rome.

-(1996): Estado mundial de la agricultura y la alimentación, Rome.

Gómez Oliver, L. (1994): La política agrícola en el nuevo estilo de desarrollo latinoamericano, Santiago, Chile, FAO.

IICA/IFPRI (International Food Policy Research Institute) (1996): Política agrícola: la búsqueda de la competitividad, sostenibilidad y equidad, Santafé de Bogotá, Unión Gráfica Ltda.

Klein, E. (1992): El empleo rural no agrícola en América Latina, Documento de trabajo No. 364, Santiago, Chile, Regional Employment Programme for Latin America and the Caribbean (PREALC).

Krueger, A. O., M. Schiff and A. Valdés (1990): Economía política de las intervenciones de precios agrícolas en América Latina, San Francisco, California, World Bank.

Peres, W. (coord.) (1998): Grandes empresas y grupos industriales latinoamericanos, Mexico City, Siglo Veintiuno Editores.

Ramos, J. (1997): Neo-liberal structural reforms in Latin America: The current situation, CEPAL Review, No. 62, LC/G.1969-P, Santiago, Chile, ECLAC.

Schejtman, A. (1982): Economía campesina y agricultura empresarial: tipología de productores del agro mexicano, Mexico City, Siglo Veintiuno Editores.

World Bank (1996): From Vision to Action, Washington, D.C. 